\title{
ALTERATIONS OF SOIL CHEMICAL PROPERTIES BY EUCALYPTUS CULTIVATION IN FIVE REGIONS IN THE RIO DOCE VALLEY(1)
}

\author{
Fernando Palha Leite ${ }^{(2)}$, Ivo Ribeiro Silva ${ }^{(3)}$, Roberto Ferreira \\ Novais $^{(3)}$, Nairam Félix de Barros ${ }^{(3)} \&$ Júlio César Lima Neves ${ }^{(3)}$
}

\begin{abstract}
SUMMARY
Little is currently known about modifications in edaphic characteristics caused by short-rotation eucalyptus and the impacts of these alterations on the sustainability of eucalyptus wood production. This study was carried out to identify theses changes at five sites of eucalyptus plantation in the region of the Rio Doce Valley, state of Minas Gerais, Brazil. Areas with more than three previous eucalyptus cycles, adjacent to pasture land or native forest, were chosen. Soil samples were collected and soil fertility analyzed by routine methods and other fractionation methods in order to measure alterations in the $\mathrm{K}, \mathrm{Ca}$ and $\mathrm{Mg}$ contents as a consequence of eucalyptus cultivation. In the eucalyptus areas, reductions in the exchangeable $\mathrm{Ca}^{2+}, \mathrm{Mg}^{2+}$ and $\mathrm{K}^{+}$contents and $\mathrm{pH}$ were observed and increased $\mathrm{Al}^{3+}$ and $\mathrm{H}+\mathrm{Al}$ contents. Of all nutrients, only $\mathrm{P}$ contents (Mehlich-1 $\mathrm{P}$ ) increased in the eucalyptus areas. The reduction in exchangeable forms and in medium-term soil nutrient pools indicates the need for higher nutrient rates than the currently applied in order to prevent nutritional limitations and soil nutrient exhaustion. After several eucalyptus rotations there was a recovery in the SOM content in comparison to degraded pasture soils, although not to the level of the native forest soil. The positive correlation between effective CEC and medium-term nonexchangeable $\mathrm{Ca}, \mathrm{Mg}$ and $\mathrm{K}$ with $\mathrm{SOM}$ emphasizes the need for adequate fertilizer and plant residue management to sustain or even increase forest productivity in future cycles.
\end{abstract}

Index terms: exchangeable cations, fertilization, nutrient exhaustion, nutrient reserves.

\footnotetext{
(1) Received for publication in November 2008 and approved in March 2010.

(2) Agronomist, Departamento de Pesquisa em Solos e Silvicultura, Celulose Nipo-Brasileira AS - CENIBRA. Email: fernando.leite@cenibra.com.br

(3) Professor, Soil Science Department, UFV. Bolsistas do CNPq. Emails: ivosilva@ufv.br; rfnovais@ufv.br; nfbarros@ufv.br; julio_n2003@yahoo.com.br
} 


\title{
RESUMO: ALTERAÇÕES DE CARACTERÍSTICAS QUÍMICAS DE SOLOS PELO CULTIVO DE EUCALIPTO EM CINCO REGIÕES NO VALE DO RIO DOCE
}

\begin{abstract}
Modificações em características edáficas, assim como as consequências resultantes dessas alterações sobre a sustentabilidade do processo de produção de madeira de eucalipto, ainda são pouco conhecidas. Com o objetivo de identificar essas modificações, realizou-se este trabalho em cinco locais cultivados com eucalipto na região do Vale do Rio Doce-MG. Foram selecionadas áreas cultivadas com eucalipto por mais de três ciclos, lado a lado com áreas onde o uso do solo ainda fosse anterior ao do plantio do eucalipto. Nestas situações (área com floresta de eucalipto próxima à área de pastagem, área de pastagem, área de eucalipto próximo à área de floresta nativa e área de floresta nativa), amostras de solo foram coletadas e analisadas, utilizando-se métodos tradicionais de avaliação da fertilidade e, também, o fracionamento de formas de $K$, Ca e Mg, para se fazer uma avaliação das alterações ocorridas nessas características do solo como consequência do cultivo do eucalipto. Nas áreas cultivadas com eucalipto, constatou-se redução nos teores de $\mathrm{Ca}^{2+}, \mathrm{Mg}^{2+}$ e $\mathrm{K}^{+}$trocáveis; redução no $\mathrm{pH}$; e aumentos nos teores de $\mathrm{Al}^{3+} \mathrm{e}$ de H+Al. Os teores de fósforo (P Mehlich-1) aumentaram nas áreas cultivadas com eucalipto. A redução das formas trocáveis e os baixos teores de nutrientes em frações não trocáveis do solo apontam para a necessidade de programas de fertilização com maior quantidade de nutrientes que a aplicada atualmente para prevenir limitações nutricionais e exaustão de nutrientes do solo. Após diversas rotações com eucalipto, houve recuperação no teor de MOS em comparação ao solo sob pastagem degradada; entretanto, esse teor ainda não retornou ao nível da floresta nativa. A correlação positiva entre CEC efetiva e reservas de médio prazo de Ca, $\mathrm{Mg}$ e K não trocáveis com a MOS enfatiza a necessidade de um adequado manejo de resíduos e fertilizantes com o objetivo de sustentar e até mesmo aumentar a produtividade das florestas em futuras rotações.
\end{abstract}

Termos de indexação: cátions trocáveis, exaustão de nutrientes, fertilização, reservas de nutrientes.

\section{INTRODUCTION}

Nowadays, the areas of eucalyptus forests in Brazil have completed a sufficient number of successive cultivation cycles (seven years per cycle) to allow the detection of alterations in some edaphic characteristics. The removal of significant amount of nutrients with the wood as well as the physical impact on the soil caused by the heavily mechanized logging process (Lira Filho et al., 1995; Dias Júnior, 2000) are considered the main causes of soil deterioration in these areas.

The introduction of clones with a higher yield potential and, consequently, with higher nutritional requirements, is most likely also an accelerating factor of chemical degradation of the soils, considering the close relationship between plant nutrient content and biomass productivity (Miller, 1984; Khanna \& Ulrich, 1984; Herbert \& Robertson, 1991; Novais \& Barros, 1997; Hernández et al., 2009). In the study of a nine year-old Eucalyptus dunnii forest in temperate climate in Uruguay, it was found that commercial logs accounted for $61 \%$ of the biomass produced, but that only $27 \%$ of the total N, $35 \%$ of the P, $8 \%$ of the K, $16 \%$ of the $\mathrm{Ca}$ and $41 \%$ of the $\mathrm{Mg}$ present in the forest were exported with the product. When logs are exported with off-site debarking, nutrient exports increase to $41,55,46,68$ and $66 \%$ of the total extraction of $\mathrm{N}, \mathrm{P}, \mathrm{K}, \mathrm{Ca}$ and $\mathrm{Mg}$, respectively (Hernández et al., 2009). Knowledge about the extent of possible deterioration, the chronology of occurrence and relations between the availability of these nutrients and forest productivity is therefore fundamental for the definition of management practices which aim at maintaining and improving in soil quality, essential for a maximum sustainable economic yield. This is particularly true in the Rio Doce Valley, Minas Gerais, a region with predominantly highly weathered soils and a mountainous landscape (Santos 1998; Amaral, 1999).

One form of quantifying the impact of eucalyptus cultivation on edaphic characteristics is a comparative evaluation of properties between soils of the same type growing eucalyptus and of adjacent areas under native vegetation or other land use, e.g., pastures (Fonseca et al., 1993; Pereira et al., 1996; Herbert, 1996; Alfredsson et al., 1998; Lima et al., 2008; Silva, 2008). In the Rio Doce Valley the soils now used for eucalyptus had predominantly been pasture or covered by native forest. These conditions serve as references since pasture and native forest soils are closer to their natural condition than the ones covered by eucalypt, and represent the other alternative of soil use in this region. 
The properties that should be used as indicators of effects of eucalyptus cultivation on soil, especially the fertility-related, are not well defined since the same chemical extractors developed for the evaluation of the soil fertility of agricultural soils are being used for forest soils. An alternative way to evaluate this effect could be the fractionation of the essential elements in compartments of distinct availability. Some previously reported alterations of soil chemical properties due to eucalyptus cultivation are: (a) reduction in the $\mathrm{pH}$ (Rhoades \& Binkley, 1996), the $\mathrm{pH}$ dependent-CEC and base saturation; (b) increase of exchangeable $\mathrm{Al}^{3+}$ (Pereira et al., 1996; Herbert, 1996); and (c) alteration in organic matter fractions (Lima et al., 2008). Lal (2005) pointed out that the soil $\mathrm{C}$ content depends on complex interactions among climate, soils, tree species and management, and the chemical composition of the litter, as determined by the dominant tree species. Substantial changes in soil organic matter (SOM) have been reported after substitution of the natural vegetation by short-rotation eucalyptus plantations (Pegoraro, 2007; Lima et al., 2008; Silva, 2008). In the Rio Doce Valley, the SOM content has been shown to be closely correlated with eucalyptus yield (Menezes, 2005). Knowledge about the impact of short-rotation eucalyptus on the short and medium-term soil nutrient reserves as well as on SOM is essential to define sustainable forestry practices. It is also likely that the changes in soil chemical properties, particularly in SOM, differ after several eucalyptus rotations, varying with the soil type and dominant climate conditions. The purpose of this study was to evaluate the effect of successive eucalyptus cultivation on a number of fertility-related edaphic characteristics in five regions in the Rio Doce Valley, Minas Gerais, Brazil.

\section{MATERIAL AND METHODS}

Five representative regions in terms of dominant soils and climatic conditions (Belo Oriente, Guanhães, Santa Bárbara, Virginópolis and Ferros) growing short-rotation eucalyptus were selected for the current study in the Rio Doce Valley, state of Minas Gerais, Brazil (Table 1). Commercial eucalyptus stands were first planted in this region in the late 60's and 70's in areas previously under unproductive pastures. Areas under eucalyptus for at least three successive rotations (over 21 years) adjacent to planted pasture or native forest (Atlantic Forest) were selected for sampling.

The Eucalyptus grandis seedlings were planted in $3 \times 2 \mathrm{~m}$ spacing, totaling 1,667 plants ha ${ }^{-1}$. Initial fertilization was applied in the planting furrow with 90 g plant $^{-1}$ of 05-25-10 NPK fertilizer followed by sidedressing of $100 \mathrm{~g} /$ plant of 10-10-20 NPK fertilizer after six months. Additional cultural practices were minimal and involved hand weeding and herbicide application. In the first two rotations, burning was commonly used to eliminate eucalyptus harvest residues. Plant nutrient analysis and wood yields were used to estimate the nutrient amounts removed from the site by harvest products in the three rotations. Fertilization records of this period were used to calculate the amount of nutrients applied to the plantations as fertilizers. Based on these data, the nutrient balance (nutrients applied through fertilizer - exported from site) were estimated for the period.

The pastures (mostly Melinis minutiflora) were established decades before eucalyptus, without liming or fertilization at sowing. Due to the limiting soil fertility, frequent burning and poor cattle management, signs of pasture yield decline were already observed by the time of sampling, with patches of barren soil exposed by surface erosion.

In 1998, six composite samples were collected at depths of $0-10,10-20,20-40$, and $40-60 \mathrm{~cm}$ at each of the five selected sites, within an area of about 3 ha, for every evaluated situation (eucalyptus next to native forest, eucalyptus next to pasture). The soil samples were air-dried, mixed and sieved $(<2 \mathrm{~mm})$ and analyzed for: $\mathrm{pH}$ in water (2.5:1) and $1 \mathrm{~mol} \mathrm{~L}^{-1} \mathrm{KCl}$; the exchangeable $\mathrm{Ca}^{2+}, \mathrm{Mg}^{2+}$ and $\mathrm{Al}^{3+}$ extracted by $1 \mathrm{~mol} \mathrm{~L}^{-1} \mathrm{KCl}$; the available $\mathrm{K}, \mathrm{P}, \mathrm{Zn}, \mathrm{Cu}, \mathrm{Fe}$, and Mn by Mehlich-1; B extracted by hot water; $\mathrm{H}+\mathrm{Al}$

Table 1. Localization and characteristics of the studied sites and eucalyptus stands in the Rio Doce Valley region

\begin{tabular}{|c|c|c|c|c|c|c|c|c|c|}
\hline Site $^{(1)}$ & Soil (2) & $\begin{array}{l}\text { Lat. } \\
\text { (W) }\end{array}$ & $\begin{array}{l}\text { Long. } \\
\text { (S) }\end{array}$ & Altitude & Climate & Prec. & Temperature & $\begin{array}{l}\text { Year started } \\
\text { planting }\end{array}$ & $\begin{array}{c}\text { Average } \\
\text { wood yield }\end{array}$ \\
\hline & & & & $\mathrm{m}$ & & $\mathrm{mm}$ & ${ }^{\circ} \mathrm{C}$ & & $\mathrm{m}^{3} \mathrm{ha}^{-1}$ year $^{-1}$ \\
\hline $\mathrm{Fe}$ & RYL & $42^{\circ} 48^{\prime}$ & $19^{\circ} 22^{\prime}$ & 930 & Cwb & 1281 & 20.7 & 1974 & 32 \\
\hline BO & RYL & $42^{\circ} 24^{\prime}$ & $19^{\circ} 14^{\prime}$ & 250 & Aw & 1163 & 25.0 & 1977 & 26 \\
\hline Gua & RYL & $42^{\circ} 57^{\prime}$ & $18^{\circ} 40^{\prime}$ & 850 & Cwa & 1192 & 21.6 & 1977 & 36 \\
\hline $\mathrm{SB}$ & $\mathrm{CX}$ & $43^{\circ} 23^{\prime}$ & $19^{\circ} 59^{\prime}$ & 847 & Cwa & 1450 & 22.3 & 1969 & 30 \\
\hline Vir & RL & $42^{\circ} 41^{\prime}$ & $18^{\circ} 42^{\prime}$ & 870 & Cwa & 1153 & 22.0 & 1975 & 42 \\
\hline
\end{tabular}

(1) Fe: Ferros; BO: Belo Oriente; Gua: Guanhães; SB: Santa Bárbara; Vir: Virginópolis. ${ }^{(2)}$ RYL: Red Yellow Latosol (Udox); RL: Red Latosol (Udox); CX: Cambissol (Udept). 
with $1 \mathrm{~mol} \mathrm{~L}^{-1} \mathrm{NH}_{4} \mathrm{OAc}(\mathrm{pH} 7.0)$; and organic carbon determined by wet oxidation of organic matter according to Walkley-Black (Embrapa, 1997). To assess the medium and long-term potential nutrient reserves of the soils, non-exchangeable, intermediate availability, $\mathrm{K}$, Ca and $\mathrm{Mg}$ were also extracted by $2 \mathrm{~mol} \mathrm{~L}^{-1}$ boiling nitric acid (Lanyon \& Heald, 1986), and more stable, low availability- K, $\mathrm{Ca}$ and $\mathrm{Mg}$ were extracted with concentrated sulfuric acid (Vettori, 1969).

The data were subjected to analysis of variance in a completely randomized design, with six replications. Orthogonal contrasts were used $(p \leq 0.10)$ for a pairwise comparison of treatment means (eucalyptus with pasture and eucalyptus with native forest) within each soil layer.

\section{RESULTS AND DISCUSSION}

The decrease in exchangeable fractions of $\mathrm{K}, \mathrm{Ca}$, and $\mathrm{Mg}$ in soils under eucalyptus as compared to those under pasture (Table 2 ) reflects the negative balance between input and output of these nutrients in the system (Table 3 ). The nutrient exported in the logs and also with plant residues removed off site after harvest may result in a significant reduction of these nutrients in the soil under the plantation management system applied in this region. The reductions in $\mathrm{Ca}$ and $\mathrm{Mg}$ were greater than of $\mathrm{K}$. On the other hand, the concentration of available P (Mehlich-1) increased in the eucalyptus areas due to $\mathrm{P}$ fertilization, leading to a positive import-export balance (Table 3). In these highly weathered soils, $\mathrm{P}$ is one of the most limiting nutrients for initial eucalyptus growth (Novais \& Barros, 1997), and its application is rarely neglected.

However, liming was not a common practice until recently because eucalyptus plants are highly Altolerant (Neves et al., 1982a; Vale et al., 1984; Silva et al., 2002, 2004) and grow well in acid soils with relatively low Ca content (Neves et al., 1982b; Vale et al., 1996). This may have added to further reduce the $\mathrm{Ca}$ and $\mathrm{Mg}$ contents of these soils.

The contents of soil organic matter (SOM) were considerably higher in soils cultivated with eucalyptus than in pasture areas (Table 2). The great amount of residues produced by the forest (leaves, branches, bark and especially roots) that remained in the areas is certainly one of the principal reasons. The quantity of harvest residues after seven years amounted to approximately, 17.0, 20.0, and $35.0 \mathrm{t} \mathrm{ha}^{-1}$ in Belo Oriente, Santa Barbara and Guanhães regions, respectively. Besides the elevated amounts of plant residues returned to the soil, the decomposition rate of these materials is presumably low, as a consequence of the low nutrient content in the dead plant material

Table 2. Chemical properties of soils under eucalyptus/pasture areas at different depths in five regions in the Rio Doce Valley

\begin{tabular}{|c|c|c|c|c|c|c|c|c|c|c|c|c|}
\hline \multirow{2}{*}{ Site } & \multicolumn{12}{|c|}{ Eucalypt/Pasture } \\
\hline & Depth & $\mathrm{pH}-\mathrm{H}_{2} \mathrm{O}$ & pH-KCl & $\Delta \mathbf{p H}$ & OM & $\mathbf{P}$ & $\mathbf{K}$ & $\mathrm{Ca}$ & Mg & Al & Total CEC & $\mathrm{Ca} / \mathrm{Al}$ \\
\hline \multirow{5}{*}{ Ferros } & $\mathrm{cm}$ & & & & $\mathrm{g} \mathrm{kg}^{-1}$ & $-\mathrm{mg}$ & $\mathrm{dm}^{-3}-$ & & $-\mathrm{cmol}$ & $\mathrm{dm}^{-3}$ & & \\
\hline & $0-10$ & $4.86 / 5.26^{(1) * *}$ & $4.27 / 4.35^{*}$ & $-0.59 /-0.91^{* *}$ & $34.5 / 30.5^{\mathrm{ns}}$ & $2.25 / 1.73^{*}$ & $23.2 / 28.8^{* *}$ & $0.09 / 0.48^{* *}$ & $0.07 / 0.25^{*}$ & $0.96 / 0.69^{\text {ns }}$ & $6.42 / 6.67^{\mathrm{ns}}$ & $0.091 / 0.688^{* *}$ \\
\hline & $10-20$ & $4.83 / 5.19^{* *}$ & $4.35 / 4.39^{\mathrm{ns}}$ & $-0.49 /-0.08^{* *}$ & $26.0 / 22.0^{0}$ & $1.64 / 1.17^{*}$ & $17.5 / 21.5^{0}$ & $0.04 / 0.23^{* *}$ & $0.05 / 0.13^{* *}$ & $0.74 / 0.73^{\mathrm{ns}}$ & $6.87 / 5.39^{\mathrm{ns}}$ & $0.060 / 0.3100^{* *}$ \\
\hline & $20-40$ & $4.89 / 5.12^{* *}$ & $4.41 / 4.45^{\mathrm{ns}}$ & $-0.48 /-0.67^{* *}$ & $18.3 / 13.8^{\mathrm{ns}}$ & $0.75 / 0.67^{\mathrm{ns}}$ & $11.0 / 15.6^{* *}$ & $0.02 / 0.10^{* *}$ & $0.03 / 0.06^{* *}$ & $0.63 / 0.52^{\mathrm{ns}}$ & $4.09 / 3.89^{\mathrm{ns}}$ & $0.035 / 0.186^{\star \star *}$ \\
\hline & $40-60$ & $4.91 / 5.06^{*}$ & $4.45 / 4.48^{\mathrm{ns}}$ & $-0.46 /-0.58^{\mathrm{ns}}$ & $12.3 / 11.8^{\text {ns }}$ & $0.47 / 0.54^{\mathrm{ns}}$ & $8.1 / 11.1^{*}$ & $0.01 / 0.09^{* *}$ & $0.02 / 0.05^{\mathrm{ns}}$ & $0.57 / 0.45^{\mathrm{ns}}$ & $3.40 / 3.40^{\text {ns }}$ & $0.022 / 0.189^{* *}$ \\
\hline \multirow{4}{*}{$\begin{array}{l}\text { Belo } \\
\text { Oriente }\end{array}$} & $0-10$ & $4.56 / 4.95^{* *}$ & $4.06 / 4.13^{\mathrm{ns}}$ & $-0.5 /-0.83^{* *}$ & $20.0 / 23.1^{\mathrm{ns}}$ & $2.73 / 1.42^{*}$ & $14.5 / 58.8^{* *}$ & $0.80 / 0.93^{\text {ns }}$ & $0.07 / 0.62^{* *}$ & $1.00 / 0.63^{\mathrm{ns}}$ & $5.99 / 6.19^{\text {ns }}$ & $0.805 / 1.462^{\mathrm{ns}}$ \\
\hline & $10-20$ & $4.46 / 4.79^{* *}$ & $4.03 / 4.03^{\mathrm{ns}}$ & $-0.43 /-0.76^{* *}$ & $16.9 / 15.5^{\mathrm{ns}}$ & $1.32 / 0.93^{*}$ & $10.2 / 32.0^{* *}$ & $0.24 / 0.63^{* *}$ & $0.03 / 0.35^{* *}$ & $1.13 / 0.82^{0}$ & $4.86 / 5.30^{\mathrm{ns}}$ & $0.213 / 0.769^{*}$ \\
\hline & $20-40$ & $4.44 / 4.78^{* *}$ & $4.07 / 4.02^{\mathrm{ns}}$ & $-0.37 /-0.75^{* *}$ & $12.6 / 10.8^{\text {ns }}$ & $0.78 / 0.62^{0}$ & $6.7 / 17.7^{* *}$ & $0.08 / 0.52^{* *}$ & $0.02 / 0.22^{* *}$ & $1.19 / 0.79^{*}$ & $4.28 / 4.47^{\mathrm{ns}}$ & $0.064 / 0.655^{*}$ \\
\hline & $40-60$ & $4.53 / 4.85^{* *}$ & $4.16 / 4.10^{\mathrm{ns}}$ & $-0.37 /-0.75^{* *}$ & $9.3 / 8.6^{\mathrm{ns}}$ & $0.62 / 0.31^{* *}$ & $3.8 / 9.1^{*}$ & $0.08 / 0.41^{* *}$ & $0.01 / 0.14^{* *}$ & $0.90 / 0.74^{\mathrm{ns}}$ & $3.22 / 3.83^{*}$ & $0.091 / 0.554^{*}$ \\
\hline \multirow[t]{4}{*}{ Guanhães } & $0-10$ & $4.45 / 4.88^{* *}$ & $3.98 / 4.16^{* *}$ & $-0.47 /-0.73^{* *}$ & $55.9 / 42.3^{* *}$ & $2.86 / 2.46^{\text {ns }}$ & $33.9 / 23.5^{* *}$ & $0.11 / 0.44^{*}$ & $0.11 / 0.2^{\mathrm{ns}}$ & $2.73 / 1.67^{* *}$ & $13.03 / 11.16^{*}$ & $0.041 / 0.26^{*}$ \\
\hline & $10-20$ & $4.57 / 4.83^{* *}$ & $4.08 / 4.18^{* *}$ & $-0.49 /-0.65^{* *}$ & $41.7 / 35.7^{0}$ & $1.87 / 0.96^{* *}$ & $27.7 / 19.0^{*}$ & $0.04 / 0.19^{*}$ & $0.07 / 0.11^{\mathrm{ns}}$ & $2.09 / 1.37^{* *}$ & 11.72 & $0.021 / 0.135^{*}$ \\
\hline & $20-40$ & $4.46 / 4.85^{* *}$ & $4.17 / 4.25^{* *}$ & $-0.29 /-0.59^{* *}$ & $27.7 / 22.1^{* *}$ & $0.68 / 0.31^{* *}$ & $14.6 / 10.1^{0}$ & $0.02 / 0.04^{* *}$ & $0.03 / 0.03^{\text {ns }}$ & $1.37 / 1.03^{* *}$ & $8.94 / 7.12^{* *}$ & $0.014 / 0.042^{* *}$ \\
\hline & $40-60$ & $4.38 / 4.72^{* *}$ & $4.28 / 4.31^{\mathrm{ns}}$ & $-0.1 /-0.40^{* *}$ & $26.2 / 16.5^{\text {** }}$ & $0.24 / 0.11^{*}$ & $6.3 / 6.4^{\mathrm{ns}}$ & $0.02 / 0.02^{\mathrm{ns}}$ & $0.01 / 0.02^{\mathrm{ns}}$ & $0.96 / 0.61^{* *}$ & $6.37 / 5.40^{* *}$ & $0.016 / 0.031^{*}$ \\
\hline \multirow{4}{*}{$\begin{array}{l}\text { Santa } \\
\text { Bárbara }\end{array}$} & $0-10$ & $4.46 /$ & $.76 / 4.17^{* *}$ & $-0.7 /-1.13^{* *}$ & $28.3 / 21.0^{* *}$ & $3.58 / 6.63^{0}$ & $32.6 / 7$ & $0.09 / 0.48^{* *}$ & $0.08 / 0.2^{* *}$ & $2.08 / 0.61^{* *}$ & & $0.041 /$ \\
\hline & $10-20$ & $4.48 / 5.03^{* *}$ & $3.86 / 4.01^{* *}$ & $-0.62 /-1.02^{* *}$ & $19.5 / 17.7^{\mathrm{ns}}$ & $1.83 / 1.87^{\mathrm{ns}}$ & $20.1 / 32.5^{*}$ & $0.04 / 0.55^{* *}$ & $0.05 / 0.19^{* *}$ & $1.78 / 0.97^{* *}$ & $8.50 / 6.61^{* * *}$ & $0.023 / 0.568^{* *}$ \\
\hline & $20-40$ & $4.55 / 4.79 * *$ & $3.89 / 3.98^{* *}$ & $-0.67 /-0.81^{* *}$ & $13.5 / 13.2^{\mathrm{ns}}$ & $1.11 / 0.99^{\text {ns }}$ & $13.0 / 19.5^{* *}$ & $0.02 / 0.18^{* *}$ & $0.06 / 0.09^{\mathrm{ns}}$ & $1.64 / 1.14^{* *}$ & $6.75 / 5.71^{*}$ & $0.015 / 0.159^{* *}$ \\
\hline & $40-60$ & $4.65 / 4.79^{0}$ & $3.93 / 4.02^{\mathrm{ns}}$ & $-0.72 /-0.77^{\mathrm{ns}}$ & $5.9 / 10.6 * *$ & $0.66 / 0.46^{\text {ns }}$ & $10.8 / 13.1^{\mathrm{ns}}$ & $0.01 / 0.17^{* *}$ & $0.08 / 0.04^{* *}$ & $1.41 / 1.01^{* *}$ & $5.41 / 4.61^{*}$ & $0.007 / 0.168^{* *}$ \\
\hline \multirow[t]{4}{*}{ Virginópolis } & $0-10$ & $4.89 / 5.07^{0}$ & $4.06 / 4.10^{\mathrm{ns}}$ & $-0.83 /-0.97^{0}$ & $52.1 / 36.8^{* *}$ & $2.40 / 0.83^{* *}$ & $24.1 / 34.8^{*}$ & $0.73 / 0.59^{\mathrm{ns}}$ & $0.24 / 0.31^{\mathrm{ns}}$ & $1.71 / 1.25^{*}$ & $11.83 / 9.40^{* *}$ & $0.427 / 0.472^{\mathrm{ns}}$ \\
\hline & $10-20$ & $4.77 / 4.95^{*}$ & $4.08 / 4.10^{\mathrm{ns}}$ & $-0.69 /-0.84^{\mathrm{ns}}$ & $45.2 / 30.1^{* *}$ & $1.88 / 0.46^{* *}$ & $19.9 / 20.8^{\mathrm{ns}}$ & $0.25 / 0.4^{\mathrm{ns}}$ & $0.13 / 0.11^{\mathrm{ns}}$ & $1.88 / 1.33^{* *}$ & $11.81 / 8.18^{* *}$ & $0.131 / 0.300^{\mathrm{ns}}$ \\
\hline & $20-40$ & $4.76 / 5.00^{*}$ & $4.11 / 4.15^{\mathrm{ns}}$ & $-0.65 /-0.85^{\mathrm{ns}}$ & $33.1 / 19.9^{* *}$ & $1.20 / 0.35^{* *}$ & $13.2 / 15^{\mathrm{ns}}$ & $0.09 / 0.22^{0}$ & $0.07 / 0.07^{\mathrm{ns}}$ & $1.68 / 1.28^{* *}$ & $10.07 / 6.38^{* *}$ & $0.054 / 0.174^{*}$ \\
\hline & $40-60$ & $4.74 / 5.11^{* *}$ & $4.16 / 4.21^{0}$ & $-0.58 /-0.9^{\text {ns }}$ & $25.9 / 15.8^{* *}$ & $0.56 / 0.12^{* *}$ & $8.3 / 10.7^{\mathrm{ns}}$ & $0.05 / 0.16^{*}$ & $0.04 / 0.05^{\mathrm{ns}}$ & $1.37 / 1.17^{0}$ & $7.79 / 5.20^{* *}$ & $0.039 / 0.133^{*}$ \\
\hline \multirow{4}{*}{$\begin{array}{l}\text { Overall } \\
\text { mean }\end{array}$} & $0-10$ & $4.64 / 5.09^{\mathrm{ns}}$ & $4.02 / 4.18^{\mathrm{ns}}$ & $-0.62 /-0.91^{\mathrm{ns}}$ & $38.2 / 30.7^{\mathrm{ns}}$ & $2.76 / 2.61^{\mathrm{ns}}$ & $25.7 / 43.5^{*}$ & $0.36 / 0.58^{\text {ns }}$ & $0.11 / 0.32^{* *}$ & $1.69 / 0.97^{*}$ & $9.49 / 7.84^{\mathrm{ns}}$ & $0.214 / 0.600^{\mathrm{ns}}$ \\
\hline & $10-20$ & $4.62 / 4.95^{0}$ & $4.08 / 4.14^{\mathrm{ns}}$ & $-0.54 /-0.81^{* *}$ & $29.9 / 24.2^{\mathrm{ns}}$ & s $1.71 / 1.08^{*}$ & $19.1 / 25.1^{0}$ & $0.12 / 0.40^{\mathrm{ns}}$ & $0.06 / 0.18^{\mathrm{ns}}$ & $1.52 / 1.04^{0}$ & $8.75 / 7.01^{\mathrm{ns}}$ & $0.081 / 0.382^{\mathrm{ns}}$ \\
\hline & $20-40$ & $4.62 / 4.91^{\mathrm{ns}}$ & $4.13 / 4.17^{\mathrm{ns}}$ & $-0.49 /-0.73^{* *}$ & $21.0 / 16.0^{\mathrm{ns}}$ & $0.90 / 0.59^{\text {ns }}$ & $11.7 / 15.6^{0}$ & $0.05 / 0.21^{*}$ & $0.04 / 0.10^{0}$ & $1.30 / 0.95^{\mathrm{ns}}$ & $6.83 / 5.51^{\mathrm{ns}}$ & $0.036 / 0.223^{*}$ \\
\hline & $40-60$ & $4.64 / 4.90^{\mathrm{ns}}$ & $4.20 / 4.22^{\mathrm{ns}}$ & $-0.44 /-0.68^{* *}$ & $=15.9 / 12.6^{\mathrm{ns}}$ & $0.51 / 0.31^{\mathrm{ns}}$ & $7.5 / 10.1^{0}$ & $0.03 / 0.17^{\text {ns }}$ & $0.03 / 0.06^{\mathrm{ns}}$ & $1.04 / 0.80^{\mathrm{ns}}$ & $5.24 / 4.49^{\text {ns }}$ & $0.033 / 0.211^{*}$ \\
\hline
\end{tabular}

$\mathrm{ns},{ }^{0}, * * *$ : contrast not significant, significant at 10,5 and $1 \%$, respectively. 
Table 3. Nutrient quantities exported with the trunks and applied to the system via fertilization in eucalyptus areas during three cycles (sums) in five studied regions of the Rio Doce Valley

\begin{tabular}{|c|c|c|c|c|c|c|c|c|c|c|c|c|c|c|c|}
\hline \multirow{2}{*}{ Site } & \multicolumn{5}{|c|}{ Quantity exported with the trunk } & \multicolumn{5}{|c|}{ Added via fertilization } & \multicolumn{5}{|c|}{ Difference (Added - exported) } \\
\hline & $\mathbf{N}$ & $\mathbf{P}$ & $\mathbf{K}$ & $\mathbf{C a}$ & $\mathrm{Mg}$ & $\mathbf{N}$ & $\mathbf{P}$ & $\mathbf{K}$ & $\mathbf{C a}$ & $\mathbf{M g}$ & $\mathbf{N}$ & $\mathbf{P}$ & K & $\mathrm{Ca}$ & $\mathrm{Mg}$ \\
\hline Fer & 367.5 & 25.8 & 253.2 & 257.7 & 60.0 & 127.5 & 61.0 & 105.4 & 40.9 & 0.0 & -240.0 & 35.2 & -147.7 & -216.7 & -60.0 \\
\hline BO & 342.3 & 32.7 & 273.3 & 543.6 & 64.2 & 127.5 & 61.0 & 105.4 & 40.9 & 0.0 & -214.8 & 28.3 & -167.8 & -502.6 & -64.2 \\
\hline Gua & 563.1 & 29.1 & 387.6 & 502.2 & 78.6 & 127.5 & 61.0 & 105.4 & 40.9 & 0.0 & -435.6 & 31.9 & -282.1 & -461.2 & -78.6 \\
\hline SB & 398.4 & 24.9 & 309.9 & 307.8 & 53.4 & 127.5 & 61.0 & 105.4 & 40.9 & 0.0 & -237.1 & 36.1 & -204.4 & -266.8 & -53.4 \\
\hline Vir & 687.9 & 37.2 & 457.5 & 923.4 & 124.2 & 127.5 & 61.0 & 105.4 & 40.9 & 0.0 & -560.4 & 23.8 & -352.0 & -882.4 & 124.2 \\
\hline
\end{tabular}

Fer:Ferros; BO: Belo Oriente; Gua: Guanhães; SB: Santa Bárbara; Vir: Virginópolis.

and soils (Gama-Rodrigues \& Barros, 2002; Zaia \& Gama-Rodrigues et al., 2004; Cunha et al., 2005). The virtual absence of soil loss by runoff in eucalyptus stands, which is common in pasture soils, may also have contributed to improve the SOM.

Short-rotation eucalyptus caused a significant drop in the $\mathrm{pH}$ in water $\left(\mathrm{pH}_{\mathrm{w}}\right.$ and in $\mathrm{KCl}\left(\mathrm{pH}_{\mathrm{K}}\right)$ in the four sampled soil layers, as compared to pasture (Table 2). Rhoades \& Binkley (1996) found a reduction in soil $\mathrm{pH}$ from 5.9 to 5.0 after eight years of E. saligna cultivation. The values of $\Delta \mathrm{pH}\left(\mathrm{pH}_{\mathrm{K}}-\mathrm{pH}_{\mathrm{w}}\right)$ also increased in the eucalyptus areas in comparison to those under pasture (Table 2), indicating that the abundance of positive charges in the soils under eucalyptus had increased, despite the increased SOM content. This pattern may affect the soil quality due to the reduction of the cation retention capacity, as well as the possibility of increase in the specific adsorption of anions such as phosphate and sulfate (Sanchez \& Uehara, 1980).

The $\mathrm{Al}^{3+}$ content in the eucalyptus areas increased in comparison to the pasture (Table 2) and as a consequence, the $\mathrm{Ca}^{2+} / \mathrm{Al}^{3+}$ ratio was lower (Table 2). This suggests, among other aspects, that the soil under eucalyptus might be a less favorable environment for fine-root growth (Khanna \& Ulrich, 1984) than previously under pasture. Although eucalyptus is known to be an Al-tolerant species, fineroot growth may be restricted by high $\mathrm{Al}^{3+}$ activities (Silva et al., 2004), especially under conditions of low $\mathrm{Ca}^{2+}$ availability. This could undermine water and nutrient uptake and eventually reduce tree growth because eucalyptus biomass yield seems to be related to fine-root growth (diameter $\leq 3.0 \mathrm{~mm}$ ) (Gatto et al., 2003).

The trends of available $\mathrm{P}, \mathrm{K}, \mathrm{Ca}$, and $\mathrm{Mg}$ in the eucalyptus soil compared to native forest soil were similar as in the comparison of eucalyptus with pasture soil. In other words, the available P (Mehlich1) increased and the exchangeable $\mathrm{K}, \mathrm{Ca}$, and $\mathrm{Mg}$ declined in the eucalyptus soils compared to the native forest areas (Table 2). However, in many cases these differences were not statistically significant, suggesting that the impact of eucalyptus on soil fertility was smaller in comparison to the native forest soils than on pasture soils. There is little nutrient exportation from the native forest, besides the fact that a major part of nutrients in native forest ecosystems in tropical regions is stored in the live and dead biomass of the forest. This fact can result in non-significant differences when the fertility of native forest soil is compared to that under eucalypt. Although large nutrient amounts are exported when eucalyptus stands are harvested, the fertilization programs keep track of these losses and amendments and fertilizes are frequently applied. Similar patterns for soil fertility were reported by Rangel \& Silva (2007) for soils under eucalypt, pasture and native forest in Lavras (MG).

The natural fertility of soils in the studied environments is low. Based on the evaluation of the nutrient reserve potential in some soils of this region, Santos et al. (1998) concluded that: a) the soil weathering stage was advanced, with predominantly kaolinitic clay material and iron and aluminum oxides (gibbsite, hematite, goethite and maghemite); b) there is practically no medium and long-term $\mathrm{K}$ reserve; and c) the relatively high exchangeable $\mathrm{Ca} /$ total $\mathrm{Ca}$ and exchangeable $\mathrm{Mg} /$ total $\mathrm{Mg}$ ratios indicate a low ability of these soils for reposition of these nutrients. Amaral (1999) evaluated physical and chemical characteristics and the capacity of nutrient supply by soils in the iron ore exploitation region in Minas Gerais, which lies in the Rio Doce basin. He found that there was virtually no soil Ca reserve, total soil $\mathrm{K}$ was limited and the total $\mathrm{Mg}$ content was also low, but with a yet lower reserve than K. Therefore, the exuberance of the native forests is not so much a consequence of soil fertility but is, in most cases, maintained by the efficiency of recycling and the accumulation of the scarce nutrients in the live and dead aboveground phytomass of the system (Jansen, 1973). Thus, fertilizers must be applied in order to avoid exhaustion of the already low soil nutrient reserves. 
The pattern of nutrient content changes in soils observed in the unproductive, degraded pasture areas can be explained by the low biomass yield of the forage grasses grown in the region, and, consequently, by the lower exportation, and/or, the lower nutrient accumulation in the biomass components of the system. The average dry matter productivity of the main forage grass of the region (Melinis minutiflora), rarely reaches $5.0 \mathrm{t} \mathrm{ha}^{-1}$ (Embrapa, 1993) and is much lower than the 12.0-20.0 $\mathrm{t} \mathrm{ha}^{-1}$ of wood yield of eucalyptus forests, indicating that the nutrient demand and hence the nutrient input, especially $\mathrm{Ca}$, $\mathrm{Mg}$ and $\mathrm{K}$ must be increased in eucalyptus forests in order to maintain the system sustainability.

The total CEC was lower in the eucalyptus than in the native forest areas, although these differences were not significant in most cases (Table 5). The $\mathrm{Al}^{3+}$ content of eucalyptus soil, was lower than those of native forest, except in Virginópolis, indicating that possible negative effects of eucalyptus cultivation concerning these characteristics also occur in areas of native forests. Chaer \& Tótola (2007) also reported a lower impact of eucalyptus cultivation on soil chemical properties in a comparison of native forest and eucalyptus under distinct managements. The soil $\mathrm{pH}$ was lower in the eucalyptus than in the native forest soil, although the difference was lower than in the comparison of eucalyptus with pasture soil (Table 5). This suggests that the determining factors of active soil acidity must be remarkably similar in both forest types (native and eucalyptus). The $\Delta \mathrm{pH}$ values were higher in the eucalyptus than in the pasture and native forest soils. Costa et al. (1984) found smaller net negative charges in an Oxisol under eucalyptus than under native forest in the region of Viçosa, Minas Gerais. In both cases the driving force for such changes was most likely the decrease in SOM.

SOM contents under eucalyptus were lower than under native forest (Table 5), indicating that the rates of organic matter addition to soil were higher in undisturbed areas (native forest). In the eucalyptus areas, in spite of the high amounts of plant residues, their quality and also some management practices such as site preparation and residue burning certainly contributed to the majority of the deposited organic residues not being incorporated into the humified SOM pool (Chaer \& Tótola, 2007; Lima et al., 2008). Much of this effect on SOM may still reflect the previous

Table 4. Concentrations of available (Mehlhich-1), non-exchangeable (extracted by $\mathrm{HNO}_{3}$ ) and more "stable" (extracted by sulfuric acid) K, Ca, and Mg in soil samples at different depths cultivated with eucalyptus/ pasture in five areas of the Rio Doce Valley region

\begin{tabular}{|c|c|c|c|c|c|c|c|}
\hline \multirow{2}{*}{ Site } & \multirow{2}{*}{ Depth } & \multicolumn{6}{|c|}{ Eucalypt/Pasture } \\
\hline & & $\mathrm{HNO}_{3}-\mathrm{K}$ & $\mathrm{H}_{2} \mathrm{SO}_{4}-\mathrm{K}$ & $\mathrm{HNO}_{3}-\mathrm{Ca}$ & $\mathrm{H}_{2} \mathrm{SO}_{4}-\mathrm{Ca}$ & $\mathrm{HNO}_{3}-\mathrm{Mg}$ & $\mathrm{H}_{2} \mathrm{SO}_{4}-\mathrm{Mg}$ \\
\hline & $\mathrm{cm}$ & $\mathrm{mg}^{-}$ & $\mathrm{dm}^{-3}$ & 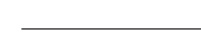 & $\mathrm{cmol}$ & $\mathrm{dm}^{-3}$ & \\
\hline \multirow[t]{4}{*}{ Ferros } & $0-10$ & $34.6 / 28.2^{0}$ & $78.0 / 84.3$ & $0.169 / 0.609 * *$ & $0.513 / 0.968$ & $0.064 / 0.182^{* *}$ & $0.463 / 0.765$ \\
\hline & $10-20$ & $23.5 / 23.2^{\mathrm{ns}}$ & $99.8 / 81.2$ & $0.071 / 0.201^{* *}$ & $0.494 / 0.576$ & $0.024 / 0.053^{\mathrm{ns}}$ & $0.918 / 0.518$ \\
\hline & $20-40$ & $15.6 / 19.2^{\mathrm{ns}}$ & $72.4 / 95.8$ & $0.035 / 0.101^{* *}$ & $0.197 / 0.572$ & $0.002 / 0.022^{\mathrm{ns}}$ & $0.675 / 0.446$ \\
\hline & $40-60$ & $9.9 / 13.6^{* *}$ & $90.6 / 81.2$ & $0.018 / 0.053^{* *}$ & $0.274 / 0.155$ & $0.001 / 0.005^{*}$ & $0.279 / 0.083$ \\
\hline \multirow[t]{4}{*}{ Belo Oriente } & $0-10$ & $23.3 / 38.7^{* *}$ & $49.8 / 55.4$ & $1.188 / 1.459^{\mathrm{ns}}$ & $0.327 / 0.766$ & $0.165 / 0.836 * *$ & $0.440 / 1.627$ \\
\hline & $10-20$ & $14.7 / 40.2^{*}$ & $62.2 / 50.3$ & $0.569 / 0.937^{\mathrm{ns}}$ & $0.556 / 0.467$ & $0.085 / 0.432^{* *}$ & $0.758 / 1.108$ \\
\hline & $20-40$ & $13.1 / 17.9^{\mathrm{ns}}$ & $37.3 / 87.1$ & $0.228 / 0.481^{*}$ & $0.184 / 0.122$ & $0.065 / 0.205^{* *}$ & $0.001 / 0.200$ \\
\hline & $40-60$ & $7.6 / 12.4^{* *}$ & $24.9 / 99.5$ & $0.131 / 0.340 * *$ & $0.087 / 0.161$ & $0.038 / 0.113^{* *}$ & $0.079 / 0.409$ \\
\hline \multirow[t]{4}{*}{ Guanhães } & $0-10$ & $44.1 / 26.9 * *$ & $203.7 / 366.7$ & $0.379 / 2.469^{\mathrm{ns}}$ & $1.043 / 4.088$ & $0.167 / 0.509^{\mathrm{ns}}$ & $2.721 / 4.981$ \\
\hline & $10-20$ & $38.5 / 19.2^{* *}$ & $117.8 / 430.0$ & $0.278 / 0.681^{\mathrm{ns}}$ & $0.865 / 1.240$ & $0.133 / 0.165^{\mathrm{ns}}$ & $1.615 / 3.175$ \\
\hline & $20-40$ & $22.1 / 11.6^{*}$ & $114.7 / 379.4$ & $0.096 / 0.097^{\mathrm{ns}}$ & $0.709 / 2.204$ & $0.070 / 0.057^{\mathrm{ns}}$ & $1.837 / 3.949$ \\
\hline & $40-60$ & $10.0 / 12.3^{\mathrm{ns}}$ & $111.6 / 392.0$ & $0.064 / 0.040^{\mathrm{ns}}$ & $0.019 / 6.079$ & $0.052 / 0.042^{\mathrm{ns}}$ & $0.626 / 7.529$ \\
\hline \multirow[t]{4}{*}{ Santa Bárbara } & $0-10$ & $48.5 / 62.6^{*}$ & $1753.2 / 396.2$ & $0.150 / 1.611^{* *}$ & $0.203 / 1.808$ & $0.125 / 0.304^{* *}$ & $2.442 / 1.658$ \\
\hline & $10-20$ & $42.7 / 45.6^{\mathrm{ns}}$ & $1669.9 / 1075.9$ & $0.074 / 0.716^{* *}$ & $0.015 / 0.67$ & $0.082 / 0.190 *$ & $2.282 / 3.552$ \\
\hline & $20-40$ & $34.9 / 42.8^{\mathrm{ns}}$ & $2351.3 / 1016.6$ & $0.045 / 0.246^{* *}$ & $0.228 / 0.157$ & $0.053 / 0.050^{\mathrm{ns}}$ & $4.180 / 3.279$ \\
\hline & $40-60$ & $43.8 / 30.4^{0}$ & $2369.6 / 427.7$ & $0.031 / 0.221^{* *}$ & $0.335 / 0.318$ & $0.054 / 0.015^{0}$ & $3.943 / 1.835$ \\
\hline \multirow[t]{4}{*}{ Virginópolis } & $0-10$ & $38.6 / 42.3^{\mathrm{ns}}$ & $112.5 / 136.9$ & $3.620 / 0.663^{\circ}$ & $2.408 / 0.758$ & $0.337 / 0.223^{\mathrm{ns}}$ & $2.218 / 1.406$ \\
\hline & $10-20$ & $35.2 / 37.1^{\mathrm{ns}}$ & $121.9 / 130.6$ & $0.674 / 0.640^{\mathrm{ns}}$ & $1.070 / 0.393$ & $0.175 / 0.116^{\mathrm{ns}}$ & $1.685 / 1.088$ \\
\hline & $20-40$ & $23.1 / 25.0^{\mathrm{ns}}$ & $121.9 / 121.6$ & $0.433 / 0.302^{\mathrm{ns}}$ & $1.280 / 0.345$ & $0.143 / 0.065^{0}$ & $2.311 / 0.902$ \\
\hline & $40-60$ & $15.9 / 23.5^{0}$ & $121.9 / 137.3$ & $0.165 / 0.284^{\mathrm{ns}}$ & $0.890 / 0.218$ & $0.083 / 0.065^{\mathrm{ns}}$ & $1.441 / 0.968$ \\
\hline \multirow[t]{4}{*}{ Overall mean } & $0-10$ & $37.8 / 39.7^{\mathrm{ns}}$ & $439.4 / 207.9^{0}$ & $1.101 / 1.362^{\mathrm{ns}}$ & $0.896 / 1.678^{\mathrm{ns}}$ & $0.172 / 0.411^{\mathrm{ns}}$ & $1.657 / 2.087^{\mathrm{ns}}$ \\
\hline & $10-20$ & $30.9 / 33.1^{\mathrm{ns}}$ & $414.3 / 353.6^{\mathrm{ns}}$ & $0.333 / 0.635^{0}$ & $0.427 / 0.669^{\mathrm{ns}}$ & $0.100 / 0.191^{\mathrm{ns}}$ & $1.452 / 1.888^{\mathrm{ns}}$ \\
\hline & $20-40$ & $21.8 / 23.3^{\mathrm{ns}}$ & $656.3 / 340.1^{\mathrm{ns}}$ & $0.167 / 0.245^{\mathrm{ns}}$ & $0.600 / 0.680^{\mathrm{ns}}$ & $0.066 / 0.080^{\mathrm{ns}}$ & $2.082 / 1.755^{\mathrm{ns}}$ \\
\hline & $40-60$ & $17.4 / 18.4^{\mathrm{ns}}$ & $543.7 / 227.5^{\mathrm{ns}}$ & $0.082 / 0.188^{\mathrm{ns}}$ & $0.321 / 1.386^{\mathrm{ns}}$ & $0.045 / 0.048^{\mathrm{ns}}$ & $1.273 / 2.165^{\mathrm{ns}}$ \\
\hline
\end{tabular}


Table 5. Chemical characteristics of soil samples at different depths in areas with eucalyptus/native forest in five areas of the Rio Doce Valley region with their respective significance of the contrast values

\begin{tabular}{|c|c|c|c|c|c|c|c|c|c|c|c|c|}
\hline \multirow{2}{*}{ Site } & \multirow{2}{*}{ Depth } & \multicolumn{11}{|c|}{ Eucalypt/Native Forest } \\
\hline & & $\mathrm{pH}-\mathrm{H}_{2} \mathrm{O}$ & pH-KCl & $\Delta \mathrm{pH}$ & OM & $\mathbf{P}$ & $\mathbf{K}$ & $\mathbf{C a}$ & Mg & Al & Total CEC & $\mathrm{Ca} / \mathrm{Al}$ \\
\hline & $\mathrm{cm}$ & & & & $\mathrm{g} \mathrm{kg}^{-1}$ & $\mathrm{mg}$ & $\mathrm{m}^{-3}$ & & & $\mathrm{cmo}$ & & \\
\hline Ferros & $\begin{array}{r}0-10 \\
10-20 \\
20-40 \\
40-60\end{array}$ & $\begin{array}{l}4.97 / 5.32^{* *} \\
4.96 / 5.41^{* *} \\
4.98 / 5.45^{* *} \\
4.94 / 5.33^{* *}\end{array}$ & $\begin{array}{l}4.16 / 4.16^{\mathrm{ns}} \\
4.24 / 4.28^{\mathrm{ns}} \\
4.47 / 4.4^{\mathrm{ns}} \\
4.6 / 4.55^{\mathrm{ns}}\end{array}$ & $\begin{array}{l}-0.81 /-1.16^{* *} \\
-0.72 /-1.13^{* *} \\
-0.52 /-1.05^{* *} \\
-0.35 /-0.78^{* *}\end{array}$ & $\begin{array}{l}48.8 / 58.3^{* *} \\
35.4 / 45.8^{* *} \\
19.8 / 33.5^{* *} \\
14.8 / 19.5^{*}\end{array}$ & $\begin{array}{l}2.71 / 1.40^{* *} \\
1.52 / 0.94^{* *} \\
0.49 / 0.56^{\text {ns }} \\
0.32 / 0.32^{\text {ns }}\end{array}$ & $\begin{array}{r}28.6 / 33.3^{*} \\
22.8 / 28.3^{*} \\
11.8 / 18.5^{* *} \\
4.9 / 10.8^{* *}\end{array}$ & $\begin{array}{l}0.09 / 0.11^{\mathrm{ns}} \\
0.05 / 0.05^{\mathrm{ns}} \\
0.01 / 0.02^{\mathrm{ns}} \\
0.01 / 0.01^{\mathrm{ns}}\end{array}$ & $\begin{array}{l}0.13 / 0.13^{\text {ns }} \\
0.09 / 0.07^{\circ} \\
0.04 / 0.05^{\text {ns }} \\
0.03 / 0.03^{\text {ns }}\end{array}$ & $\begin{array}{l}1.38 / 1.76^{*} \\
1.01 / 1.25^{*} \\
0.54 / 0.93^{* *} \\
0.33 / 0.51^{* *}\end{array}$ & $\begin{array}{l}9.55 / 11.08^{*} \\
7.04 / 8.44^{\mathrm{ns}} \\
3.95 / 6.41^{* *} \\
3.16 / 4.24^{* *}\end{array}$ & $\begin{array}{l}0.064 / 0.064^{\text {ns }} \\
0.047 / 0.042^{\text {ns }} \\
0.027 / 0.021^{\text {ns }} \\
0.042 / 0.019^{\text {ns }}\end{array}$ \\
\hline $\begin{array}{l}\text { Belo } \\
\text { Oriente }\end{array}$ & $\begin{array}{r}0-10 \\
10-20 \\
20-40 \\
40-60\end{array}$ & $\begin{array}{l}4.08 / 4.35^{*} \\
4.13 / 4.32^{*} \\
4.16 / 4.45^{* *} \\
4.21 / 4.59^{* *}\end{array}$ & $\begin{array}{l}3.75 / 3.84^{\mathrm{ns}} \\
3.86 / 3.88^{\mathrm{ns}} \\
3.94 / 3.96^{\mathrm{ns}} \\
4.03 / 4.08^{\mathrm{ns}}\end{array}$ & $\begin{array}{l}-0.33 /-0.51^{*} \\
-0.27 /-0.44^{*} \\
-0.22 /-0.49^{* *} \\
-0.18 /-0.52^{* *}\end{array}$ & $\begin{array}{l}24.3 / 35.0^{* *} \\
17.5 / 25.8^{* *} \\
14.7 / 18.0^{*} \\
10.7 / 13.3^{*}\end{array}$ & $\begin{array}{l}3.01 / 1.78^{0} \\
2.01 / 1.31^{* *} \\
1.29 / 0.75^{* *} \\
0.91 / 0.44^{* *}\end{array}$ & $\begin{array}{c}28.6 / 33.6^{\text {ns }} \\
19.5 / 26.2^{\text {ns }} \\
11.5 / 21.3^{*} \\
6.6 / 12.1^{* *}\end{array}$ & $\begin{array}{l}0.12 / 0.06^{\text {ns }} \\
0.05 / 0.05^{\text {ns }} \\
0.03 / 0.04^{\text {ns }} \\
0.02 / 0.07^{\text {ns }}\end{array}$ & $\begin{array}{l}0.09 / 0.11^{\text {ns }} \\
0.05 / 0.08^{\text {ns }} \\
0.03 / 0.06^{\text {ns }} \\
0.02 / 0.04^{\text {ns }}\end{array}$ & $\begin{array}{l}1.82 / 1.87^{\mathrm{ns}} \\
1.61 / 1.72^{\mathrm{ns}} \\
1.40 / 1.37^{\mathrm{ns}} \\
1.28 / 1.09^{\mathrm{ns}}\end{array}$ & $\begin{array}{l}8.66 / 9.80^{\text {ns }} \\
6.60 / 8.50^{* *} \\
4.67 / 6.09^{* *} \\
3.69 / 4.55^{* *}\end{array}$ & $\begin{array}{l}0.067 / 0.033^{\mathrm{ns}} \\
0.031 / 0.028^{\mathrm{ns}} \\
0.018 / 0.026^{\mathrm{ns}} \\
0.016 / 0.062^{\mathrm{ns}}\end{array}$ \\
\hline Guanhães & $\begin{array}{r}0-10 \\
10-20 \\
20-40 \\
40-60\end{array}$ & $\begin{array}{l}4.33 / 4.65^{* *} \\
4.39 / 4.74^{* *} \\
4.33 / 4.81^{* *} \\
4.22 / 4.86^{* *}\end{array}$ & $\begin{array}{l}3.83 / 3.94^{*} \\
4.00 / 4.06^{*} \\
4.12 / 4.17^{* *} \\
4.21 / 4.25^{* *}\end{array}$ & $\begin{array}{l}-0.49 /-0.72^{* *} \\
-0.4 /-0.69^{* *} \\
-0.21 /-0.64^{* *} \\
-0.01 /-0.62^{* *}\end{array}$ & $\begin{array}{l}48.2 / 54.7^{\text {s }} \\
33.3 / 43.4^{* *} \\
23.9 / 29.7^{\text {** }} \\
17.7 / 21.8^{0}\end{array}$ & $\begin{array}{l}2.02 / 1.52^{\text {ns }} \\
0.92 / 0.85^{\text {ns }} \\
0.42 / 0.41^{\text {ns }} \\
0.15 / 0.19^{\text {ns }}\end{array}$ & $\begin{array}{c}37.2 / 38.2^{\mathrm{ns}} \\
23 / 26.7^{\mathrm{ns}} \\
13.2 / 14^{\mathrm{ns}} \\
8.8 / 9.8^{\mathrm{ns}}\end{array}$ & $\begin{array}{l}0.08 / 0.07^{\text {ns }} \\
0.02 / 0.02^{\text {ns }} \\
0.01 / 0.01^{\text {ns }} \\
0.01 / 0.02^{\text {ns }}\end{array}$ & $\begin{array}{l}0.12 / 0.09^{\text {ns }} \\
0.05 / 0.06^{\text {ns }} \\
0.03 / 0.03^{\text {ns }} \\
0.02 / 0.02^{\text {ns }}\end{array}$ & $\begin{array}{l}2.09 / 2.03^{\text {ns }} \\
1.39 / 1.42^{\text {ns }} \\
0.93 / 0.94^{\text {ns }} \\
0.60 / 0.57^{\text {ns }}\end{array}$ & $\begin{array}{l}14.82 / 14.81^{\mathrm{ns}} \\
10.77 / 11.61^{\mathrm{ns}} \\
7.86 / 8.75^{*} \\
5.58 / 634^{* *}\end{array}$ & $\begin{array}{l}0.038 / 0.035^{\text {ns }} \\
0.012 / 0.017^{\text {ns }} \\
0.008 / 0.016^{\text {ns }} \\
0.018 / 0.028^{\text {ns }}\end{array}$ \\
\hline $\begin{array}{l}\text { Santa } \\
\text { Bárbara }\end{array}$ & $\begin{array}{r}0-10 \\
10-20 \\
20-40 \\
40-60\end{array}$ & $\begin{array}{l}4.53 / 4.55^{\mathrm{ns}} \\
4.57 / 4.57^{\mathrm{ns}} \\
4.65 / 4.60^{\mathrm{ns}} \\
4.76 / 4.79^{\mathrm{ns}}\end{array}$ & $\begin{array}{l}3.96 / 3.84^{*} \\
3.99 / 3.92^{* *} \\
4.05 / 3.91^{* *} \\
4.09 / 3.95^{* *}\end{array}$ & $\begin{array}{l}-0.57 /-0.7^{*} \\
-0.58 /-0.65^{\mathrm{ns}} \\
-0.6 /-0.69^{0} \\
-0.67 /-0.84^{* *}\end{array}$ & $\begin{array}{l}23.6 / 28.4^{0} \\
19.0 / 22.2^{*} \\
15.3 / 15.5^{\mathrm{ns}} \\
11.2 / 8.9^{0}\end{array}$ & $\begin{array}{l}1.85 / 2.75^{\mathrm{ns}} \\
0.97 / 1.80^{*} \\
0.32 / 0.80^{* *} \\
0.08 / 0.37^{0}\end{array}$ & $\begin{array}{c}25.8 / 38.9^{\text {ns }} \\
18.5 / 27.3^{0} \\
9.6 / 16.5^{* *} \\
7.1 / 10.7^{*}\end{array}$ & $\begin{array}{l}0.04 / 0.12^{\text {ns }} \\
0.03 / 0.07^{\text {ns }} \\
0.02 / 0.03^{\text {ns }} \\
0.02 / 0.02^{\text {ns }}\end{array}$ & $\begin{array}{l}0.05 / 0.12^{\text {ns }} \\
0.04 / 0.07^{0} \\
0.02 / 0.04^{\text {ns }} \\
0.02 / 0.02^{\text {ns }}\end{array}$ & $\begin{array}{l}1.94 / 2.40^{* *} \\
1.92 / 2.29^{* *} \\
1.57 / 1.74^{\mathrm{ns}} \\
1.44 / 1.30^{\mathrm{ns}}\end{array}$ & $\begin{array}{l}7.64 / 9.07^{*} \\
7.06 / 7.54^{\text {ns }} \\
5.56 / 6.02^{\text {ns }} \\
4.50 / 4.50^{\text {ns }}\end{array}$ & $\begin{array}{l}0.019 / 0.050^{\mathrm{ns}} \\
0.013 / 0.031^{\mathrm{ns}} \\
0.012 / 0.019^{\mathrm{ns}} \\
0.012 / 0.018^{\mathrm{ns}}\end{array}$ \\
\hline ginópolis & $\begin{array}{r}0-10 \\
10-20 \\
20-40 \\
40-60\end{array}$ & $\begin{array}{l}4.74 / 5.16^{* *} \\
4.71 / 5.13^{* *} \\
4.78 / 5.14^{* *} \\
4.98 / 5.16^{*}\end{array}$ & $\begin{array}{l}4.01 / 4.11^{* *} \\
4.11 / 4.16^{* *} \\
4.20 / 4.25^{0} \\
4.26 / 4.30^{0}\end{array}$ & $\begin{array}{l}-0.73 /-1.04^{* *} \\
-0.61 /-0.97^{\mathrm{ns}} \\
-0.58 /-0.9^{\mathrm{ns}} \\
-0.72 /-0.86^{\mathrm{ns}}\end{array}$ & $\begin{array}{l}62.7 / 59.0^{*} \\
49.3 / 45.0^{\text {ns }} \\
39.3 / 33.7^{0} \\
30.8 / 25.8^{*}\end{array}$ & $\begin{array}{l}2.33 / 1.43^{* *} \\
1.68 / 1.23^{\text {ns }} \\
1.10 / 0.66^{0} \\
0.71 / 0.48^{*}\end{array}$ & $\begin{array}{c}22.1 / 33.2^{*} \\
18.3 / 23.8^{\text {ns }} \\
12.3 / 13.3^{\text {ns }} \\
8.1 / 9.8^{\text {ns }}\end{array}$ & $\begin{array}{l}0.05 / 0.67^{*} \\
0.02 / 0.30^{0} \\
0.01 / 0.12^{\text {ns }} \\
0.01 / 0.07^{\text {ns }}\end{array}$ & $\begin{array}{l}0.05 / 0.35 \\
0.05 / 0.16 \\
0.04 / 0.08 \\
0.02 / 0.06\end{array}$ & $\begin{array}{l}2.20 / 1.50^{* *} \\
1.93 / 1.43^{* *} \\
1.38 / 1.07^{* *} \\
1.06 / 0.93^{\text {ns }}\end{array}$ & $\begin{array}{l}11.37 / 11.22^{\text {ns }} \\
10.09 / 9.22^{*} \\
7.72 / 7.32^{\text {ns }} \\
6.39 / 5.79^{\text {ns }}\end{array}$ & $\begin{array}{l}0.023 / 0.445^{0} \\
0.012 / 0.210^{\text {ns }} \\
0.008 / 0.113^{\text {ns }} \\
0.007 / 0.080^{\text {ns }}\end{array}$ \\
\hline $\begin{array}{l}\text { Overall } \\
\text { mean }\end{array}$ & $\begin{array}{r}0-10 \\
10-20 \\
20-40 \\
40-60\end{array}$ & $\begin{array}{l}4.53 / 4.81^{\mathrm{ns}} \\
4.55 / 4.83^{\mathrm{ns}} \\
4.58 / 4.89^{\mathrm{ns}} \\
4.62 / 4.95^{\mathrm{ns}}\end{array}$ & $\begin{array}{l}3.94 / 3.98^{\mathrm{ns}} \\
4.04 / 4.06^{\mathrm{ns}} \\
4.16 / 4.14^{\mathrm{ns}} \\
4.24 / 4.22^{\mathrm{ns}}\end{array}$ & $\begin{array}{l}-0.59 /-0.83^{* *} \\
-0.51 /-0.77^{*} \\
-0.43 /-0.75^{* *} \\
-0.38 /-0.72^{* *}\end{array}$ & $\begin{array}{l}41.5 / 47.1^{\text {ns }} \\
30.9 / 36.5^{\text {ns }} \\
22.6 / 26.1^{\text {ns }} \\
17.1 / 17.9^{\text {ns }}\end{array}$ & $\begin{array}{l}2.38 / 1.77^{\mathrm{ns}} \\
1.42 / 1.23^{\mathrm{ns}} \\
0.72 / 0.63^{\mathrm{ns}} \\
0.43 / 0.36^{\mathrm{ns}}\end{array}$ & $\begin{array}{c}28.4 / 35.4^{\mathrm{ns}} \\
20.4 / 26.5^{0} \\
11.7 / 16.7^{*} \\
7.1 / 10.7^{*}\end{array}$ & $\begin{array}{l}0.08 / 0.21^{\mathrm{ns}} \\
0.03 / 0.10^{\mathrm{ns}} \\
0.02 / 0.04^{\mathrm{ns}} \\
0.01 / 0.04^{\mathrm{ns}}\end{array}$ & $\begin{array}{l}0.09 / 0.16^{\text {ns }} \\
0.06 / 0.09^{\text {ns }} \\
0.03 / 0.05^{\text {ns }} \\
0.02 / 0.03^{\text {ns }}\end{array}$ & $\begin{array}{l}1.89 / 1.91^{\mathrm{ns}} \\
1.57 / 1.62^{\mathrm{ns}} \\
1.16 / 1.21^{\mathrm{ns}} \\
0.94 / 0.88^{\text {ns }}\end{array}$ & $\begin{array}{l}10.41 / 11.19^{\mathrm{ns}} \\
8.31 / 9.06^{\mathrm{ns}} \\
5.95 / 6.92^{\mathrm{ns}} \\
4.66 / 5.09^{\mathrm{ns}}\end{array}$ & $\begin{array}{l}0.040 / 0.108^{\text {ns }} \\
0.021 / 0.061^{\text {ns }} \\
0.013 / 0.037^{\text {ns }} \\
0.015 / 0.043^{\text {ns }}\end{array}$ \\
\hline
\end{tabular}

$\mathrm{ns} ;{ }^{0} ; * ; *$ : contrast not significant; significant at $10 ; 5$; and $1 \%$, respectively.

land use (unproductive pastures) and may therefore not be an exclusive effect of short-rotation eucalypt. In fact, studies using the natural abundance of the ${ }^{13} \mathrm{C}$ isotope indicate that the SOM content is slowly recovered after planting short-rotation eucalyptus in soils formerly under degraded, unproductive pastures (Lima et al., 2006).

The variations observed in the $\mathrm{Ca}^{2+} / \mathrm{Al}^{3+}$ ratios between the eucalyptus and native forest soils were not significant. There larger decreases in this ratio were observed when comparing eucalyptus with pasture soils. Rangel \& Silva (2007) found that in soils under eucalyptus the $\mathrm{Ca}^{2+} / \mathrm{Al}^{3+}$ ratio $(0.32)$ was close to that reported for soils under native forest (0.39), but much higher (13.5) than in pasture soil.

When establishing eucalyptus in pasture land, the sustainability of the wood production could be negatively affected by the low availability of $\mathrm{K}^{+}, \mathrm{Ca}^{2+}$ and $\mathrm{Mg}^{2+}$ and the reduction of the $\mathrm{pH}$ and $\mathrm{Ca}^{2+} / \mathrm{Al}^{3+}$ ratio, the higher $\mathrm{Al}^{3+}$ contents, and the increase of positive soil charges. Yet, the observed changes in properties such as SOM and Mehlich-1 P suggest that the activity would be sustainable.

Considering the native forest soil as reference, these alterations indicate that the sustainability of wood production as affected by the availability of $\mathrm{K}$, $\mathrm{Ca}, \mathrm{Mg}$ would be lower than in the system where pasture land is converted to eucalyptus forest.
However, the high SOM losses observed indicates that this property could reduce the sustainability. The results suggest that the main causes for yield reductions observed in some cases after the first rotation are most likely also due to alterations in soil physical rather than only chemical properties.

SOM contents were highly correlated with CEC $\left(\mathrm{r}=0.9^{* * *}\right), \mathrm{Al}^{3+}\left(\mathrm{r}=0.5^{* * *}\right), \mathrm{K}^{+}\left(\mathrm{r}=0.45^{* * *}\right)$, and with $\mathrm{P}\left(\mathrm{r}=0.33^{* *}\right)$. However, no correlation was found with exchangeable $\mathrm{Ca}$ and $\mathrm{Mg}$ because most of the negative charges in these soils were occupied by $\mathrm{Al}^{3+}$. The finding that most effective negative charges in these soils are SOM-dependent is not surprising because of the high weathering degree and dominance of the clay fraction by low-activity minerals. It also indicates the importance of maintaining SOM at these eucalyptus sites. For soils in the same region, Menezes (2005) found that SOM and solution equilibrium P were the only two soil properties correlated with eucalyptus yield. The author pointed out that SOM content and solution equilibrium $\mathrm{P}$ are properties associated to the extension of the surface as well as quality of the solid phase. Consequently, SOM plays an important role in production sustainability which is why it is widely used as soil quality indicator.

Evaluations of intermediate and more "stable" nutrient fractions indicated that intermediate availability (non-exchangeable) and long-term 
("stable") reserves of $\mathrm{K}, \mathrm{Ca}$ and $\mathrm{Mg}$ are limited, (Tables 4 and 6) and are consistent with the advanced weathering stage of these soils. According to limits suggested by Resende \& Santana (1988) $(\mathrm{Ki} \leq 0.75$ and $\mathrm{Kr} \leq 0.75$ ), the soils of all five studied areas contained secondary minerals where the clay fraction consisted predominantly of gibbsite and sesquioxides, that is, highly weathered materials. In this study there was a significant correlation between SOM content and $\mathrm{HNO}_{3}-\mathrm{Ca}$ and $\mathrm{HNO}_{3}-\mathrm{Mg}\left(\mathrm{r}=0.3^{* * *}\right)$, and $\mathrm{HNO}_{3}-\mathrm{K}$ contents $\left(\mathrm{r}=0.4^{* * *}\right)$, indicating that SOM also contributes to nutrient supply in the medium term.

The $\mathrm{HNO}_{3}-\mathrm{K}$ contents (available plus moderately available forms) were up to 3.8 times higher than those of Mehlich 1-K (available forms) (Table 7). Silva et al. (1996) found that some native woody species are able to use non-exchangeable $\mathrm{K}$ forms. If these $\mathrm{K}$ forms are really the most appropriate to estimate available $\mathrm{K}$ for eucalyptus (Melo et al., 1995), the current fertilization based on exchangeable $\mathrm{K}^{+}$contents would be leading to inaccurate recommendations. On the other hand, not only exchangeable, but also nonexchangeable and more "stable" $\mathrm{K}$ fractions were depleted after three eucalyptus rotations, suggesting that higher K fertilizer doses than the currently used should be applied to eucalyptus stands on these soils. The negative balance between $\mathrm{K}$ exported from and $\mathrm{K}$ applied via fertilizers to the site (Table 3) support this hypothesis.

The $\mathrm{HNO}_{3}-\mathrm{K} /$ Mehlich-1 $\mathrm{K}$ ratio differed markedly between the regions (Table 7); Belo Oriente had the lowest and the Santa Barbara region the highest ratio. The ratio increased with soil depth as a result of lower K values (Mehlich 1). Amaral (1999) also reported this pattern in soils of the Santa Barbara region. To create a fertilizer recommendation systems based on the nutritional balance for eucalypt, however, deeper layers should also be included. Melo et al. (1995) studied $\mathrm{K}$ and $\mathrm{Mg}$ forms in less weathered soils of southern Brazil and their relation to eucalyptus

Table 6. Concentrations of available/exchangeable forms and the intermediate availability (extracted with $\mathrm{HNO}_{3}$ ) and "stable" forms (extracted by sulfuric acid) of $\mathrm{K}$, Ca, and $\mathrm{Mg}$ in soil samples at different depths of eucalyptus or native forest in five areas of the Rio Doce Valley region with their respective significance of contrast values

\begin{tabular}{|c|c|c|c|c|c|c|c|}
\hline \multirow{2}{*}{ Site } & \multirow{2}{*}{ Depth } & \multicolumn{6}{|c|}{ Eucalypt/Native forest } \\
\hline & & $\mathrm{HNO}_{3}-\mathrm{K}$ & $\mathrm{H}_{2} \mathrm{SO}_{4}-\mathrm{K}$ & $\mathrm{HNO}_{3}-\mathrm{Ca}$ & $\mathrm{H}_{2} \mathrm{SO}_{4}-\mathrm{Ca}$ & $\mathrm{HNO}_{3}-\mathrm{Mg}$ & $\mathrm{H}_{2} \mathrm{SO}_{4}-\mathrm{Mg}$ \\
\hline \multirow{5}{*}{ Ferros } & $\mathrm{cm}$ & \multicolumn{2}{|c|}{$\mathrm{mg} \mathrm{dm}^{-3}$} & \multicolumn{4}{|c|}{$\longrightarrow \mathrm{cmol}_{\mathrm{c}} \mathrm{dm}^{-3}$} \\
\hline & $0-10$ & $39.9 / 43.0 \mathrm{~ns}$ & $43.7 / 87.2$ & $0.186 / 0.140^{\mathrm{ns}}$ & $0.319 / 0.268$ & $0.105 / 0.077^{\mathrm{ns}}$ & $1.440 / 0.511$ \\
\hline & $10-20$ & $29.1 / 36.8^{*}$ & $49.9 / 80.9$ & $0.082 / 0.091^{\mathrm{ns}}$ & $0.189 / 0.109$ & $0.030 / 0.081^{\mathrm{ns}}$ & $0.740 / 0.622$ \\
\hline & $20-40$ & $15.1 / 27.9 * *$ & $43.7 / 77.8$ & $0.019 / 0.035^{\mathrm{ns}}$ & $0.014 / 0.005$ & $0.000 / 0.030 *$ & $0.532 / 1.050$ \\
\hline & $40-60$ & $12.4 / 15.2^{* *}$ & $62.4 / 77.8$ & $0.012 / 0.001^{\mathrm{ns}}$ & $0.125 / 0.000$ & $0.000 / 0.000^{\mathrm{ns}}$ & $0.988 / 0.438$ \\
\hline \multirow[t]{4}{*}{ Belo Oriente } & $0-10$ & $30.2 / 38.6^{0}$ & $849.0 / 70.5$ & $0.126 / 0.111^{\mathrm{ns}}$ & $0.154 / 0.194$ & $0.118 / 0.153^{\mathrm{ns}}$ & $0.600 / 0.743$ \\
\hline & $10-20$ & $21.6 / 32.5 \mathrm{~ns}$ & $25.2 / 30.2$ & $0.062 / 0.074^{\mathrm{ns}}$ & $0.271 / 0.303$ & $0.080 / 0.111^{\mathrm{ns}}$ & $0.686 / 0.675$ \\
\hline & $20-40$ & $15.6 / 22.9^{*}$ & $75.4 / 32.7$ & $0.045 / 0.057^{\mathrm{ns}}$ & $0.565 / 0.271$ & $0.061 / 0.083^{\mathrm{ns}}$ & $0.810 / 0.749$ \\
\hline & $40-60$ & $9.40 / 13.6^{* *}$ & $140.0 / 22.7$ & $0.033 / 0.037^{\mathrm{ns}}$ & $0.285 / 0.192$ & $0.044 / 0.06^{\mathrm{ns}}$ & $0.827 / 0.456$ \\
\hline \multirow[t]{4}{*}{ Guanhães } & $0-10$ & $41.0 / 46.4 \mathrm{~ns}$ & $49.0 / 49.2$ & $0.209 / 0.151^{\mathrm{ns}}$ & $0.126 / 0.142$ & $0.158 / 0.139^{\mathrm{ns}}$ & $0.432 / 0.156$ \\
\hline & $10-20$ & $30.6 / 30.7 \mathrm{~ns}$ & $49.0 / 49.0$ & $0.096 / 0.058^{\mathrm{ns}}$ & $0.077 / 0.357$ & $0.096 / 0.083^{\mathrm{ns}}$ & $0.286 / 1.048$ \\
\hline & $20-40$ & $15.4 / 20.4 \mathrm{~ns}$ & $265.2 / 36.8$ & $0.03 / 0.0220^{\mathrm{ns}}$ & $0.310 / 0.145$ & $0.056 / 0.057^{\mathrm{ns}}$ & $2.774 / 0.583$ \\
\hline & $40-60$ & $8.7 / 15.4^{* *}$ & $265.6 / 36.8$ & $0.009 / 0.022^{\mathrm{ns}}$ & $0.212 / 0.364$ & $0.041 / 0.176^{*}$ & $3.785 / 1.533$ \\
\hline \multirow[t]{4}{*}{ Santa Bárbara } & $0-10$ & $53.0 / 61.5^{\mathrm{ns}}$ & $1574.7 / 1930.9$ & $0.094 / 0.213^{\mathrm{ns}}$ & $0.301 / 0.07$ & $0.119 / 0.155^{\mathrm{ns}}$ & $3.524 / 2.848$ \\
\hline & $10-20$ & $52.6 / 45.8^{\mathrm{ns}}$ & $2245.1 / 2082.4$ & $0.083 / 0.121^{\mathrm{ns}}$ & $0.103 / 0.090$ & $0.120 / 0.097^{\mathrm{ns}}$ & $4.309 / 2.837$ \\
\hline & $20-40$ & $41.8 / 33.5^{\mathrm{ns}}$ & $2731.4 / 2104.2$ & $0.047 / 0.064^{\mathrm{ns}}$ & $0.055 / 0.024$ & $0.075 / 0.062^{\mathrm{ns}}$ & $5.083 / 2.937$ \\
\hline & $40-60$ & $38.0 / 47.1^{\mathrm{ns}}$ & $2768.8 / 1774.3$ & $0.033 / 0.031^{\mathrm{ns}}$ & $0.052 / 0.014$ & $0.067 / 0.112^{*}$ & $5.377 / 2.123$ \\
\hline \multirow[t]{4}{*}{ Virginópolis } & $0-10$ & $37.9 / 48.7 *$ & $171.3 / 173.7$ & $0.408 / 2.068^{\mathrm{ns}}$ & $0.327 / 0.622$ & $0.178 / 0.551^{*}$ & $1.703 / 1.502$ \\
\hline & $10-20$ & $32.3 / 31.6^{\mathrm{ns}}$ & $161.7 / 161.2$ & $0.105 / 0.856^{*}$ & $0.255 / 0.485$ & $0.103 / 0.256^{* *}$ & $1.641 / 0.840$ \\
\hline & $20-40$ & $21.9 / 20.9^{\mathrm{ns}}$ & $143.1 / 149.7$ & $0.046 / 0.400^{0}$ & $0.107 / 0.422$ & $0.040 / 0.179 * *$ & $0.888 / 1.527$ \\
\hline & $40-60$ & $16.6 / 17.6^{\mathrm{ns}}$ & $171.1 / 153.1$ & $0.059 / 0.290^{*}$ & $0.115 / 1.187$ & $0.023 / 0.135^{* *}$ & $1.068 / 1.995$ \\
\hline \multirow[t]{4}{*}{ Overall mean } & $0-10$ & $40.4 / 47.6^{\mathrm{ns}}$ & $537.5 / 462.3^{\mathrm{ns}}$ & $0.205 / 0.537^{\mathrm{ns}}$ & $0.245 / 0.259^{\mathrm{ns}}$ & $0.136 / 0.215^{n s}$ & $1.540 / 1.152^{\mathrm{ns}}$ \\
\hline & $10-20$ & $33.2 / 35.5^{\mathrm{ns}}$ & $506.2 / 480.8^{\mathrm{ns}}$ & $0.085 / 0.240^{\mathrm{ns}}$ & $0.179 / 0.268^{\mathrm{ns}}$ & $0.086 / 0.125^{n s}$ & $1.532 / 1.205^{\mathrm{ns}}$ \\
\hline & $20-40$ & $22.0 / 25.1^{\mathrm{ns}}$ & $651.7 / 480.2^{\mathrm{ns}}$ & $0.038 / 0.116^{\mathrm{ns}}$ & $0.210 / 0.178^{\mathrm{ns}}$ & $0.046 / 0.082 \mathrm{~ns}$ & $2.017 / 1.369^{\mathrm{ns}}$ \\
\hline & $40-60$ & $17.0 / 21.8^{\mathrm{ns}}$ & $681.6 / 412.9^{\mathrm{ns}}$ & $0.029 / 0.076^{\mathrm{ns}}$ & $0.158 / 0.351^{\mathrm{ns}}$ & $0.035 / 0.097 *$ & $2.409 / 1.309^{\mathrm{ns}}$ \\
\hline
\end{tabular}

ns; ${ }^{0} ; * * *$ : contrast not significant; significant at $10 ; 5$; and $1 \%$, respectively. 
Table 7. Non-exchangeable to exchangeable K, Ca, and Mg ratios in soil samples taken from eucalyptus stands at different depths in the five studied regions

\begin{tabular}{|c|c|c|c|c|c|c|c|c|c|c|c|c|}
\hline \multirow{2}{*}{ Site } & \multicolumn{12}{|c|}{ Depth (cm) } \\
\hline & $0-10$ & $10-20$ & $20-40$ & $40-60$ & $0-10$ & $10-20$ & $20-40$ & $40-60$ & 0-10 & $10-20$ & $20-40$ & $40-60$ \\
\hline & \multicolumn{4}{|c|}{ Potassium } & \multicolumn{4}{|c|}{ Calcium } & \multicolumn{4}{|c|}{ Magnesium } \\
\hline Ferros & 1.31 & 1.28 & 1.41 & 1.54 & 1.39 & 1.17 & 1.19 & 0.65 & 0.73 & 0.55 & 0.29 & 0.04 \\
\hline Belo Oriente & 0.97 & 1.27 & 1.27 & 1.44 & 1.40 & 1.58 & 1.15 & 0.87 & 1.36 & 1.34 & 1.23 & 1.18 \\
\hline Guanhães & 1.21 & 1.26 & 1.36 & 1.50 & 4.44 & 3.93 & 2.87 & 2.22 & 1.80 & 1.64 & 1.85 & 4.33 \\
\hline Santa Bárbara & 1.31 & 1.91 & 2.64 & 3.81 & 2.76 & 1.38 & 1.49 & 1.36 & 1.56 & 1.37 & 1.11 & 1.57 \\
\hline Virginópolis & 1.50 & 1.66 & 1.67 & 1.96 & 3.46 & 2.51 & 2.64 & 2.68 & 1.42 & 1.51 & 1.66 & 1.70 \\
\hline Mean & 1.25 & 1.48 & 1.69 & 2.15 & 2.55 & 1.94 & 1.70 & 1.40 & 1.36 & 1.29 & 1.22 & 1.48 \\
\hline
\end{tabular}

growth and nutrient content, and concluded that the non-exchangeable $\mathrm{K}$ forms were essential for eucalyptus nutrition. Lana \& Neves (1994) evaluated the capacity of $\mathrm{K}$ supply in eucalyptus soils and found that the non-exchangeable $\mathrm{K}$ forms $\left(\mathrm{HNO}_{3}-\mathrm{K}\right.$ minus $\mathrm{NH}_{4} \mathrm{OAc}-\mathrm{K}$ ) were responsible, on average, for $70 \%$ of the $\mathrm{K}$ taken up by the plants. The average $\mathrm{H}_{2} \mathrm{SO}_{4}-\mathrm{K} /$ $\mathrm{HNO}_{3}-\mathrm{K}$ ratio at the evaluated sites varied from 1.54 to 53.61. These values also increased in greater soil depths, once again emphasizing the need to include the contribution of nutrients from deeper layers in the fertilizer recommendation programs.

The $\mathrm{HNO}_{3}$-Ca contents were also considerably higher than those extracted by $1 \mathrm{~mol} \mathrm{~L}^{-1} \mathrm{KCl}$ (Tables 4, and 6). The $\mathrm{HNO}_{3}-\mathrm{Ca} / \mathrm{KCl}-\mathrm{Ca}$ ratio decreased with increasing depth (Table 7), suggesting that the contribution of mineral forms to Ca reserves. Indeed, up to $70 \%$ of $\mathrm{Ca}$ taken up by eucalyptus is incorporated in the bark and slowly released during decomposition. Exchangeable $\mathrm{Ca}^{2+}$ contents found in the present study are below the critical levels suggested for eucalyptus (Novais \& Barros, 1997). These findings, combined with the reduced nonexchangeable $\mathrm{Ca}\left(\mathrm{HNO}_{3}-\mathrm{Ca}\right.$ minus $\left.\mathrm{KCl}-\mathrm{Ca}\right)$ and "stable" Ca forms of the soil $\left(\mathrm{Ca}-\mathrm{H}_{2} \mathrm{SO}_{4}\right)$, are further aggravated by the fact that the greatest reserves are found in the upper layers (and therefore more exposed to losses by erosive processes), supporting the idea that this nutrient is the most critical for the maintenance of the sustainability of eucalyptus forests on these soils. The reposition of this element through limestone would not only supply $\mathrm{Ca}$, but also ameliorate soil acidity. Similar conclusions were drawn in a study evaluating nutrient use efficiency and yield sustainability of $E$. grandis and $E$. saligna in São Paulo State (Santana et al., 2002).

The contents of $\mathrm{HNO}_{3}-\mathrm{Mg}$ and $\mathrm{H}_{2} \mathrm{SO}_{4}-\mathrm{Mg}$ were not very different from the exchangeable $\mathrm{Mg}^{2+}(\mathrm{Mg}-\mathrm{KCl})$ (Tables 4, 6 and 7), indicating a reduced medium-term potential of $\mathrm{Mg}$ supply by these soils. Unlike $\mathrm{K}$ and $\mathrm{Ca}$, no clear trend with increasing depth was observed for the $\mathrm{HNO}_{3}-\mathrm{Mg} / \mathrm{KCl}-\mathrm{Mg}$ ratio.

\section{CONCLUSIONS}

1. The management practices applied in eucalyptus forests in the last three decades caused significant alterations in some soil chemical properties, indicating that independently of the previous land use (native forest or pasture), the readily available and long-term nutrient contents were reduced (except P). These differences were greater when soils under eucalyptus were compared to pasture than to forest soils.

2. Soil organic matter levels were recovered after several eucalyptus rotations, but they are still intermediary to the degraded pasture and native forest soils.

3. There are clear indications that in order to maintain and improve soil chemical properties under eucalyptus forests, the nutrient balance should be strictly controlled, mainly through fertilization, liming and harvest residue management to prevent soil nutrient depletion and plant deficiency.

4. The depletion of exchangeable and nonexchangeable $\mathrm{K}, \mathrm{Ca}$ and $\mathrm{Mg}$ fractions and the increase in soil acidity and positive charges emphasizes the need for preservation of plant residues at the site in order to avoid drastic reductions in soil organic matter, which could undermine the sustainability of eucalyptus production. In this region, not only soil $\mathrm{CEC}$, but also medium-term $\mathrm{Ca}, \mathrm{Mg}$ and $\mathrm{K}$ pools are related to the soil organic matter content.

\section{ACKNOWLEDGEMENTS}

Dr. I.R. Silva is thankful for financial support from the National Council for Scientific and Technological Development-CNPq. Continuous financial support from FAPEMIG-Fundação de Amparo a Pesquisa de Minas Gerais to the NUTREE research group has also been fundamental. Logistics, accomodations and help personnel for soil sampling were kindly provided 
by CENIBRA. Finally, we also would like to thank the Associate Editor and one anonimous reviewer for their valuable suggestions.

\section{LITERATURE CITED}

ALFREDSSON, H.; CONDRON, L.M.; CLARHOLM, M. \& DAVIS, M.R. Changes in soil acidity and organic matter following the establishment of conifers on former grassland in New Zealand. For. Ecol. Manag., 112, 233244, 1998

AMARAL, G. Influência de características químicas e físicas de cinco diferentes solos da zona metalúrgica mineira na produtividade de eucalipto. Viçosa, MG, Universidade Federal de Viçosa, 1999. 109p. (Tese de Mestrado)

CHAER, G.M. \& TÓTOLA, M.R. Impacto do manejo de resíduos orgânicos durante a reforma de plantios de eucalipto sobre indicadores de qualidade do solo. R. Bras. Ci. Solo, 31:13811396, 2007.

COSTA, L.M.; MORAIS, E.J.; RIBEIRO, A.C. \& FONSECA, S. Cargas elétricas de um Latossolo vermelho-amarelo com diferentes coberturas florestais. R. Ceres, 31:351-359, 1984.

CUNHA, G.M.; GAMA-RODRIGUES, A.C. \& COSTA, G.S. Ciclagem de nutrientes em Eucalyptus grandis W. Hill ex Maiden no norte fluminense. R. Árvore, 29:353-363, 2005 .

DIAS JÚNIOR, M.S. Compactação do solo. In: NOVAIS, R.F.; ALVAREZ V., V.H. \& SCHAEFER, C.E.G.R., eds. Tópicos em ciência do solo. Viçosa, MG, Sociedade Brasileira de Ciência do Solo, 2000. p.55-94.

EMPRESA BRASILEIRA DE PESQUISA AGROPECUÁRIA . EMBRAPA. Algumas considerações sobre gramíneas e leguminosas forrageiras. Coronel Pacheco, 1993. 59p.

EMPRESA BRASILEIRA DE PESQUISA AGROPECUÁRIA EMBRAPA. Centro Nacional de Pesquisa de Solos. Manual de métodos de análise de solo. Rio de Janeiro, 1997. $212 \mathrm{p}$

FONSECA, S.; BARROS, N.F.; NOVAIS, R.F.; COSTA, L.M.; LEAL, P.L. \& NEVES, J.C.L. Alterações em um Latossolo sob eucalipto, mata natural e pastagem. I. Propriedades físicas e químicas. R. Árvore, 17:271-288, 1993.

GAMA-RODRIGUES, A.C. \& BARROS, N.F. Ciclagem de nutrientes em floresta natural e em plantios de eucalipto e de dandá no sudeste da Bahia, Brasil. R. Árvore, 26:193207, 2002

GAMA-RODRIGUES, E.F.; BARROS, N.F.; GAMARODRIGUES, A.C. \& SANTOS, G.A. Nitrogênio, carbono e atividade da biomassa microbiana do solo em plantações de eucalipto. R. Bras. Ci. Solo, 29:893-901, 2005.

GATTO, A.; BARROS, N.F.; NOVAIS, R.F.; COSTA, L.M. \& NEVES, J.C.L. Efeito do método de preparo do solo, em área de reforma, nas suas características, na composição mineral e na produtividade de plantações de eucalyptus grandis. R. Árvore, 27:635-646, 2003.
HERBERT, M.A. \& ROBERTSON, M.A. Above-ground biomass composition and nutrient content for Eucalytus species in the Southeastern Transvaal. In: SCHÖNAL, A.P.G., ed. SYMPOSIUM ON INTENSIVE FORESTRY: The role of eucalypts. Pretoria, Southern African Institute of Forestry, 1991. p.662-674.

HERBERT, M.A. Fertilizers and eucalypt plantations in South Africa. In: ATTIWILL, P.M. \& ADAMS, M.A., eds. Nutrition of eucalypts. Collingwood, CSIRO Publishing, 1996. p.303326.

HERNÁNDEZ, J.; PINO, A.; DEL; SALVO, L. \& ARRARTE, G. Nutrient export and harvest residue decomposition patterns of a Eucalyptus dunnii Maiden plantation in temperate climate of Uruguay. For. Ecol.Manag., 258:9299, 2009

JANSEN, D.H. Tropical agroecosystems. Sci., 182:1212-1219, 1973

KHANNA, P.H. \& ULRICH, B. Soil characteristics influencing nutrient supply in forest soil. In: BOWEN, G.D. \& NAMBIAR, E.K.S., eds. Nutrition of plantation forests. London, Academic Press, 1984. p.79-118.

LAL, R. Forest soils and carbon sequestration. For. Ecol. Manag., 220:242-258, 2005.

LANA, M.C. \& NEVES, J.C.L. Capacidade de suprimento de potássio em solos sob reflorestamento com eucalipto do estado de São Paulo. R. Árvore, 18:115-122, 1994.

LANYON, L.E. \& HEALD, W.R. Magnesium, calcium, strontium and barium. In: PAGE, A., ed. Methods of soil analysis: Chemical and microbiological properties. Madison, American Society of Agronomy, 1986. Part 2. p.247-262

LIMA, A.M.N.; SILVA, I.R.; NEVES, J.C.L.; NOVAIS, R.F.; BARROS, N.F.; MENDONÇA, E.S.; SMYTH, T.J.; MOREIRA, M.S. \& LEITE, F.P. Soil organic carbon dynamics following afforestation of degraded pastures with eucalyptus in southeastern Brazil. For. Ecol. Manag., 235:219-23, 2006.

LIMA, A.M.N.; SILVA, I.R.; NEVES, J.C.L.; NOVAIS, R.F.; BARROS, N.F.; MENDONÇA, E.S.; DEMOLINARI, M.S.M. \& LEITE, F.P. Frações da matéria orgânica do solo após três décadas de cultivo de eucalipto no vale do Rio Doce - MG. R. Bras. Ci. Solo, 32:1053-1063, 2008.

LIRA FILHO, J.A.; ARRIEL, E.F. \& SOUTO, J.S. Impactos em solos de floresta plantada decorrentes da colheita e transporte de madeira. In: CONGRESSO BRASILEIRO DE CIÊNCIA DO SOLO, 25., Viçosa, MG, 1995. Resumos. Viçosa, MG, Sociedade Brasileira de Ciência do Solo, 1995. p.1942-1944.

MELO, V.F.; BARROS, N.F.; COSTA, L.M.; NOVAIS, R.F. \& FONTES, M.P.F. Formas de potássio e de magnésio em solos do Rio Grande do Sul, e sua relação com o conteúdo na planta e com a produção em plantios de eucalipto. R. Bras.Ci. Solo, 19:165-171, 1995.

MENEZES, A.A. Produtividade do eucalipto e sua relação com a qualidade e a classe de solo. Viçosa, MG, Universidade Federal de Viçosa, 2005. 98p. (Tese de Doutorado) 
MILLER, H.G. Dynamics of nutrient cycling in plantation ecosystems. In: ALDOUS, J.R., ed. Wood for energy: The implications for harvesting, utilization and marketing. Edinburgh, Institute of Chartered Foresters, 1984. p.137146 .

NEVES, J.C.L.; NOVAIS, R.F. \& BARROS, N.F. Effect of aluminum in nutrient solution on growth and nutrient uptake by Eucalyptus spp. R. Árvore, 6:1-16, 1982a.

NEVES, J.C.L.; NOVAIS, R.F.; BARROS, N.F. \& ANJOS, L.J. Efeito do alumínio em dois Latossolos de cerrado no crescimento e absorção de nutrientes por mudas de Eucalyptus spp. R. Árvore, 6:17-28, 1982b.

NOVAIS, R.F. \& BARROS, N.F. Sustainable agriculture and forestry production systems on acid soil: Phosphorus as a case-study. In: MONIZ, A.C., ed. Plant-soil interactions at low pH. Campinas, Sociedade Brasileira de Ciência do Solo, 1997. p.39-51.

PEGORARO, R.F. Sequestro de carbono e alterações bioquímicas da matéria orgânica de solos cultivados com eucalipto. Viçosa, MG, Universidade Federal de Viçosa, 2007. 140p. (Tese de Doutorado)

PEREIRA, J.S.; TOMÉ, M.; MADEIRA, M.; OLIVEIRA, A.C.; TOMÉ, J.\& ALMEIDA, M.H. Eucalypt plantations in Portugal. In: ATTIWILL, P.M. \& ADAMS, M.A., eds. Nutrition of eucalypts. Collingwood, CSIRO, 1996. p.371388.

RANGEL, O.J.P. \& SILVA, C.A. Estoques de carbono e nitrogênio e frações orgânicas de Latossolo submetido a diferentes sistemas de uso e manejo. R. Bras. Ci. Solo, 31:1609-1623, 2007.

RESENDE, M. \& SANTANA, D.P. Uso das relações Ki e Kr na estimativa da mineralogia para classificação dos Latossolos. In: REUNIÃO DE CLASSIFICAÇÃO, CORRELAÇÃO DE SOLOS E INTERPRETAÇÃO DE APTIDÃO AGRÍCOLA, 3., Rio de Janeiro, 1988. Anais. Rio de janeiro, Empresa Brasileira de Pesquisa Agropecuária, 1988. p.225-232.

RHOADES, C. \& BINKLEY, D. Factors influencing decline in soil $\mathrm{pH}$ in Hawaiian Eucalyptus and Albizia plantations. For. Ecol. Manag., 80:47-56, 1996.

SANCHEZ, P.A. \& UEHARA, G. Management considerations for acid soils with high phosphorus fixation capacity. In: KHASAWNEH, F.E.; SAMPLE, E.C. \& KAMPRATH, E.J., eds. The role of phosphorus in agriculture. Madison, American Society of Agronomy, 1980. p.471-514.
SANTANA, R.C.; BARROS, N.F. \& NEVES, J.C.L. Eficiência de utilização de nutrientes e sustentabilidade da produção em procedências de Eucalyptus grandis e Eucalyptus saligna em sítios florestais do Estado de São Paulo. R. Árvore, 26:447-457, 2002.

SANTOS, A.R.; FONTES, M.P.F.; ALVAREZ V., H.V.; RESENDE, M.; KER, J.C. \& COSTA, L.M. Caracterização mineralógica, potencial de reserva e sustentabilidade agrícola de alguns sítios florestais de eucalipto da região do Vale do Rio Doce (MG). R. Bras. Ci. Solo, 22:255-266, 1998.

SILVA, I.R.; NOVAIS, R.F.; JHAM, G.; BARROS, N.F.; GEBRIM, F.O.; NUNES, F.N.; NEVES, J.C.L. \& LEITE, F.P. Responses of eucalypt species to aluminum: The possible involvement of low molecular weight organic acids in the Al tolerance mechanism. Tree Physiol., 24:1267-1277, 2004.

SILVA, E.F. Frações da matéria orgânica e decomposição de resíduos da colheita de eucalipto em solos de tabuleiros costeiros da Bahia. Viçosa, MG, Universidade Federal de Viçosa, 2008. 124p. (Tese de Dotourado)

SILVA, I.R.; FURTINI NETO, A.E.; VALE, F.R. \& CURI, N. Eficiência nutricional para potássio em espécies florestais nativas. R. Bras. Ci. Solo, 20:257-264, 1996.

SILVA, I.R.; SMYTH, T.J.; BARROS, N.F. \& NOVAIS, R.F. Physiological aspects of aluminum toxicity and tolerance in plants. In: ALVAREZ V, V.H.; SCHAEFER, C.E.G.R.; BARROS. N.F.; MELLO, J.W.V. \& COSTA, L.M., eds. Topicos em ciência do solo. Viçosa, MG, Sociedade Brasileira de Ciência do Solo. Viçosa, MG, 2002. p.277335.

VALE, F.R.; FURTINI NETO, A.E.; RENÓ, N.B.; FERNANDEZ. L. \& RESENDE, A.V. Root growth of forest species in acid soil. Pesq. Agropec. Bras., 31:609-616, 1996.

VALE, F.R.; NOVAIS, R.F.; BARROS, N.F. \& SANT'ANA, R. Efeito do alumínio na cinética de absorção de nitrato e amônio por raízes intactas de Eucalyptus alba. R. Árvore, 8:123-132, 1984.

VETTORI, L. Métodos de análise de solo. Rio de Janeiro, Ministério de Agricultura, Equipe de Pedologia e Fertilidade do Solo, 1969. 24p. (Boletim Técnico, 7)

ZAIA, F.C. \& GAMA-RODRIGUES, A.C. Ciclagem e balanço de nutrientes em povoamentos de eucalipto na região norte fluminense. R. Bras. Ci. Solo, 28:843-852, 2004. 